\title{
Revitalization of Handloom Communities for Preserving the Craft Heritage of Bangladesh
}

\author{
Faria Sharmin", Sharif Tousif Hossain \\ Department of Architecture, Stamford University Bangladesh, Dhaka, Bangladesh \\ Email address: \\ faria.sharmin.buet@gmail.com (F. Sharmin), imon_architecture@yahoo.com (S. T. Hossain) \\ ${ }^{*}$ Corresponding author
}

\section{To cite this article:}

Faria Sharmin, Sharif Tousif Hossain. Revitalization of Handloom Communities for Preserving the Craft Heritage of Bangladesh. Urban and Regional Planning. Special Issue: Management of the City - A Multi-Branch Task. Vol. 5, No. 1, 2020, pp. 1-10.

doi: $10.11648 /$ j.urp.20200501.11

Received: December 27, 2019; Accepted: February 13, 2020; Published: February 24, 2020

\begin{abstract}
In Bangladesh there is a huge possibility in the sector of low cost industry and handloom is the prominent one of them. The Handloom Industry is one of the oldest cultural heritages of Bangladesh, which is mostly accomplished as a home based industry involving traditional crafts like muslin, jamdani, tanter saree that they have inherited from their ancestors. These products are the major part of our low cost industry and also a part of history and heritage of our country. Handloom industries, once dominated in the apparel sector of the subcontinent are on the verge of disappearance due to a couple of reasons like lack of preservation, dedicated space, manpower crisis, breaking down of communities, product competitiveness, lack of marketing skill etc. Some communities nearby Dhaka such as Tangail, Mymensign, Kishoreganj, Narayanganj, Narsingdi, Kaliakoir has been working in the sector of handloom for a long period of time. But because of the breaking the bonding of those community and lack of preservation of their heritage this sector is now losing their interest. For restoring the community bonding and preserving the heritage there could be created a common interconnected space. Gazipur Sadar is such a place which resides in between all those six districts. There are a good national, regional and local linkage through infrastructure between those areas and Gazipur Sadar. As there are no specific spaces of those communities to exhibit and sell their products; an area in Gazipur Sadar near Chilai Khal, could be proposed as an expo area for reviving the heritage of those handlooms communities. This study recommends developing a heritage hub to revitalize these communities as well as promoting their handloom industries both nationally and internationally.
\end{abstract}

Keywords: Handloom Industry, Cultural Heritage, Traditional Craft, Community Revitalization, Heritage, Preservation

\section{Introduction}

The traditional handloom industry is an age-old traditional and largest cottage industry of Bangladesh. Next to agriculture, handloom industry is the second largest non-agricultural source of rural employment in this country [1]. The traditional handloom industry is Bangladesh's most significant non-farm operation since a long time ago, which has provided rural poor, and particularly women, huge employment opportunities [2]. Among 164.69 million (census 2020) [3] of total population about more than 1.5 million people are directly or indirectly involved in this industry for their livelihood [4]. Handloom plays a key role on the livelihood of our rural people by generating local employment and linking with other sectors. It has generated many opportunities for a large number of people. The knowledge and expertise need for this field is transformed from the forefathers of the rural people. According to Bangladesh Handloom Board (BHB) [5] Handloom industries consist of about 183 thousands handloom unit with 505 thousands of Handloom machines. However the number of active loom is about 300 thousand, which is the source of income of about 1 million workforce including weavers, dyers, spinners, embroiders and related artisans work. Beanarashi, Jamdani, Tant Sarees and Lungi are the top handloom products manufactured in number of factories throughout the countries. Each year these small industries fabricated 687 million meters of fabrics [5]. In Bangladesh the practice of handloom can be seen throughout the country, however it is traditionally concentrated in Dhaka, Pabna, 
Cumilla and Tangail. Among those the capital of Bangladesh Dhaka has patronized this craft significantly. Dhaka and its surrounding areas like Tangail, Mymensign, Narayanganj, Narshindhi, Kishoegong, Gazipur etc have long been established as an important center for handloom products due to expertise in craftsmanship and specialize products. These areas account for about 33\% of total operational capacity an about $35 \%$ of total employment [5]. Thus the handloom communities of these six districts have been selected as a sample area. The productions of these industries get to the central market through a primary and secondary network; thus meet the significant part of the requirements of clothes for people and other activities in the country. The present condition of these handloom industries are questionable, however future prospects of this sector are very splendid as well as have a glorious past. The present scenario of handloom weaving is disputed and the number of weavers of the industry is decreasing in an alarming rate as a lot of internal and external factors have a direct impact on the handloom industry of ours [6].

Among the various reasons, the serious laborer shortage of these traditional arts and crafts producing regions is mainly due to inadequate space for both working and marketing, lack of contemporary technology based marketing and preservation skill and absence of direct connection of the artisans to the local and international markets, as well as lack of product diversification and organizational Problem. Due to these problems, it is difficult to secure highly skilled young laborers as the artisans get older but also causes a break in the process of handing down technologies and skills to the next generation. Thus causes a rapid decline of traditional craft communities of these areas.

In clothing sector Bangladesh government has established restructuring and relocating the sector due to solve the problem of disinclination for increasing the basic market. Bangladesh clothing industry as most preferential for international buyers can bring back normalcy in the capital by relocating and offering more opportunities to other suitable cities outside Dhaka, as Dhaka is facing innumerable problems due to over population. Industrial Clusters are logically considered as an effective platform to enhance production and improve quality and increase job opportunity of clothing sector (Relocating of clothing industry of Dhaka) [7].

To understand the reason of decreasing the number of loom units in the six districts surrounding Dhaka where notable number of loom industries is located, the study conducts random interview and questionnaire survey among the local artisans. The statistical and geographical information, photographs and other information of handloom industries are collected from secondary sources.

The handloom industry of the surrounding districts of Dhaka is on the virtue of distinction for above mentioned reasons. For solving this problem and for maintaining the sustainable growth of handloom industry the relocation of working and marketing place can be considered as an effecting platform to enhance both production and selling nationally and internationally. For revitalizing the products of these handloom communities the study may suggest an international business hub where the craftsmen from all over the country as well as from other countries can exhibit and sell their products by their own.

\section{Literature Review}

Handloom is a wood or iron (some portion) made device, used for producing woven fabric. It is generally run by man with hand and foot without any electric motor. Since the long past the handloom products of Bangladesh are well known in Asia and Europe. Until the 17th century "Muslins" was acclaimed throughout the world because of its singular beauty and finest quality [8]. It was the favorite cloth of the aristocrat families including kings.

Queens and nobles of the court. Moreover muslin was the major export items in the early British period (1757-1947). After independence in 1971, the handloom industry was the most dominant supplier of cloth of Bangladesh [9]. Since 1972 handloom products have shown a significant upward trend in exporting products in overseas markets. Handloom products of ours with their superior quality and unique design have created a pathway for themselves in the foreign markets [10]. This sector has a great potentiality to meet the extensive needs of clothing in the export oriented garments industry. Inadequate distribution of channel is one of the noteworthy problems in this case to match between demand and supply [11]. Handloom industry of Bangladesh is now on the way of extinction because of various problems and obstruction adjacent to this industry. In our country weavers do not get quality raw materials at the right time and at the right price [12]. Now a day's the number of handlooms decreases day by day due to unequal competitiveness with cost effective power looms operated by the entrepreneurs for the introduction of new and high value-added fashionable products. The other prominent factors and barriers those are responsible for the extinction to this industry are also identified. According to Ghosh and Akhter [11], shortage of capital, increasing price of raw materials, insufficient transport facilities, inadequate technology and efficiency in operating the loom by the new generation, migration of the Bangladeshi weavers due to lack of security and better facilities in India are the factors those are slowing down the wheels of this industry. Moreover lack of government and non- government policy support to industrialize the products nationally and internationally is one of the significant factors for decreasing the number of operational handlooms day by day.

\section{Objective of the Research}

This research is aimed to expose the barriers and problems of the Handloom industry of the above selected communities near Dhaka. Then the study tried to understand the explicit reasons why these communities breaking their bondage and lacking their interest on preserving the heritage thus to provide 
a solution to these specific problems. Our broad objective is to identify the potential market of handloom sector and to generate a guideline for the re-establishment of these communities nationally and internationally thus the craftsman may sustain and preserve the culture of handloom from extinction.

\section{Research Methodology}

To conduct the study primary and secondary data are used for analysis. The research uses literature review and observational method for selecting the six communities' near Dhaka, where remarkable number of loom industries are located. To get the present scenario of these communities and to find the reason for decreasing the number of looms the study go through an open ended random field analysis through interview and questionnaire survey. Statistical data are analyzed to identify the cause behind year by year downwards movement of the number of total person engaged in this industry. Finally analyzing all the data a suggestion is given to revitalize the handloom communities.

\section{Selection of Sample Area}

The present study mainly based on different six handloom communities which are located in the northern side of the capital city of Dhaka. Those Districts are around 18 miles [figure 1] catchment distance from Dhaka by road. Those six communities are located in the districts of Tangail, Mymensingh, Narayanganj, Narsingdi, Kishoreganj \& Gazipur are marked with red dots in figure 1. There are many looms and handlooms concentrated areas around those districts. Like, Tangail has a glorious history of its own because of Tangail Sharee which has a great reputation within and outside of the country [5]. Narsingdi is well known for its handloom weaving [13]. Then Narayanganj district where a large number of famous Jamdani Sharee is been waved and circulated all over the country [14]. From tables $1 \& 2$ it is apparent that like these communities the other three communities are also well known for the existence of loom industry. The pleasant past history of loom industry and presence of numbers loom weaving families of those nearby six loom communities are the reason to select those places as a sample area (Report on Bangladesh Handloom Census, 1990, 2003 \& 2011) and (District Statistics, 2011), which are easily accessible from Dhaka city.

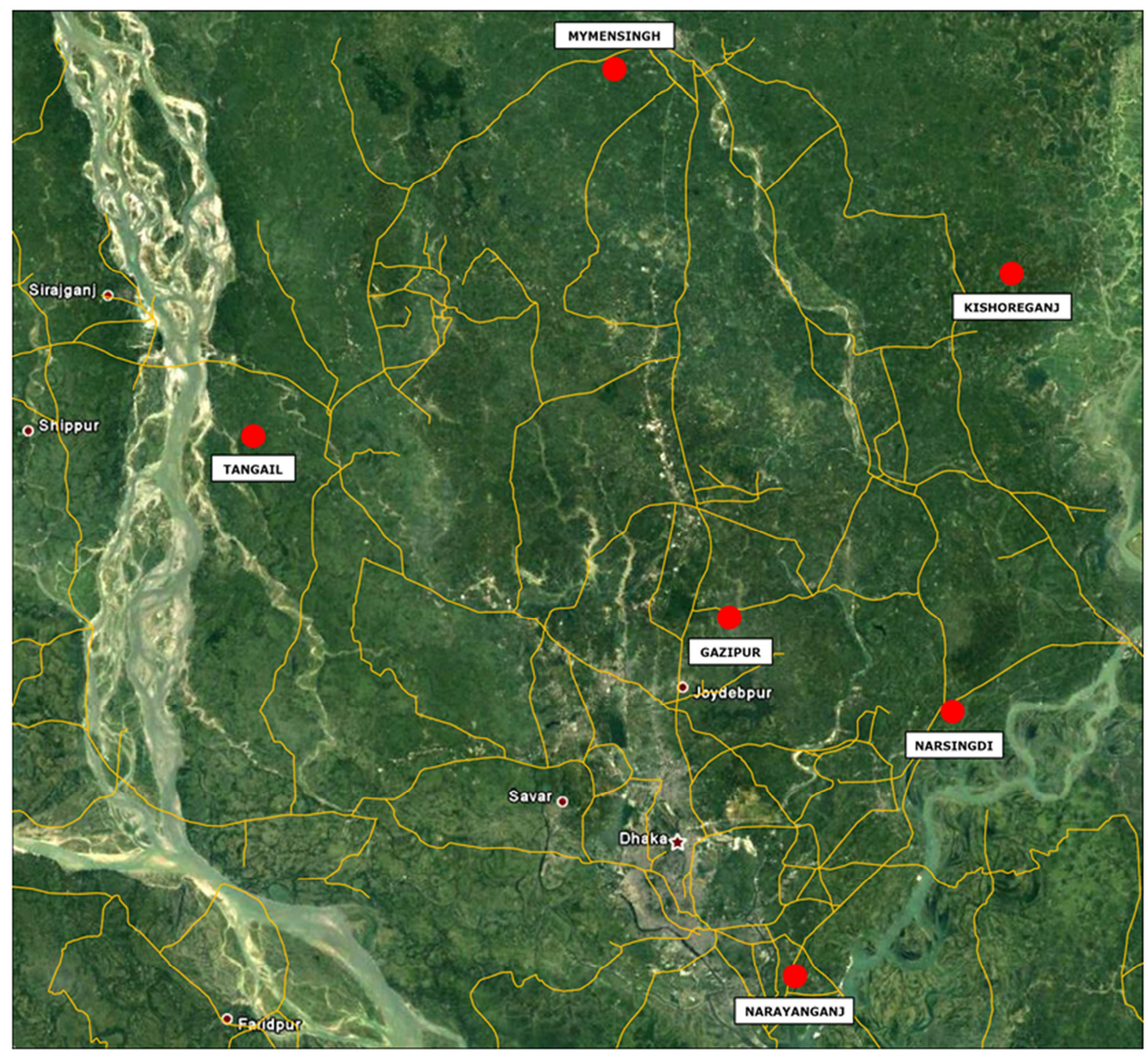

Figure 1. Location map of six Districts with road connectivity. 


\section{Data Collection}

The study uses primary and secondary data for analysis. To get the present scenario and to collect the information in 2017 the study go through an open ended random field analysis through interview and questionnaire survey among the 60 local entrepreneurs of the mentioned six communities who are the producers and suppliers of the loom products. In the next stage all those districts upazilas loom related statistics like number of units, number of looms (both operational and non-operational), how many persons engaged are collected from Bangladesh Handloom Census 1990, 2003 \& District statistics 2011 as after this period no data has been updated from the government. Past and Present scenario of handloom sector of those districts are also collected from different journals and literature review and article. From those reports some loom related statistics of those districts in different years $(1990,2003 \& 2011)$ are collected to understand the present condition of loom industry. The number of unit and number of looms (operational and non-operational) are given below in

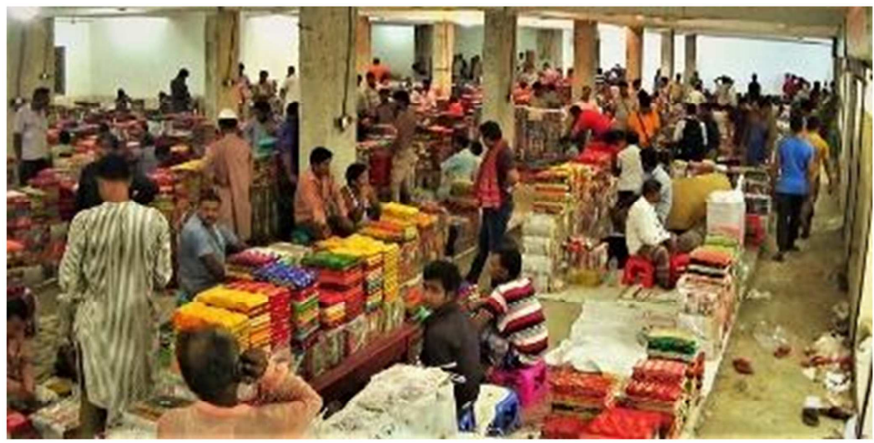

Tangail-Karatia-Haat.

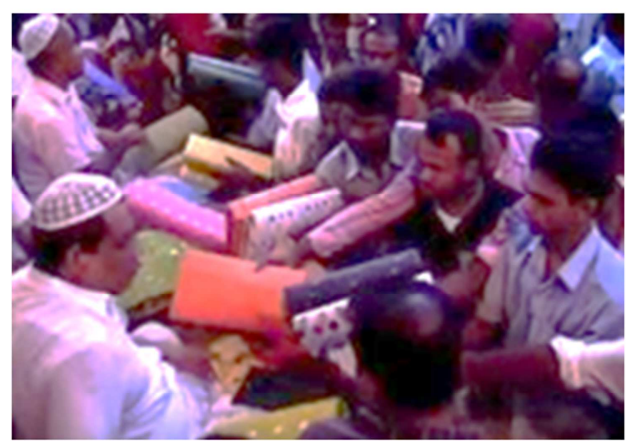

Rupgonj Jamdani palli. the tables $1 \& 2$. Then total number of person which was working in the year of 2003 and 2011 of those districts are collected. Which are given below in the table $3[15,16]$

Handloom industry of those selected districts has a glorious history of their own. From the ancient period traditionally skilled artisans are working in those areas. Like Tangail is famous for the product Tangail sharee. This sharee is produced only in Tangail and named Tangail saree from the name of the district Tangail. Bajitpur Haat, Karotia Bazar is the known market where this product is selling around customers which is shown in figure 2. Each year huge number of sharees are produced by the industry and supplies all over the world. Every week neighborhood country India received around 50,000 piece sharee from government of Bangladesh [3]. Handloom industry of Tangail district has the International patent of Tangail Sharee. Twice in every week weavers sell the sharee in the nearest haat of Bazitpur and Korotia. Fashion houses from Dhaka and other districts come in Tangail haat to buy product from the local weavers and retailers because of the easy accessibility by road and railway [5].

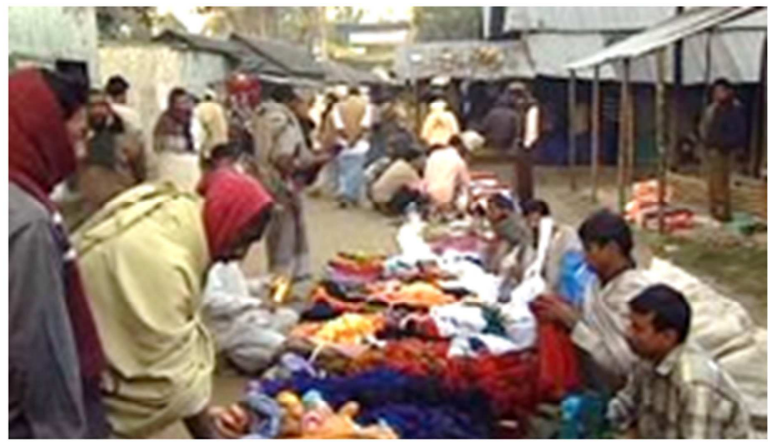

Bajitpur Haat.

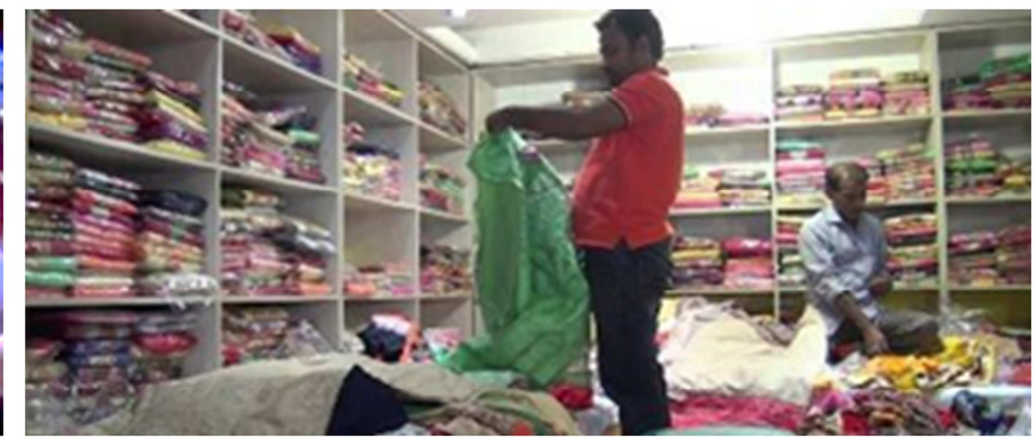

Narsingdi Baburhat Bazar.

Figure 2. Scenario of Haat \& Bazar in different six Districts.

Table 1. Number of units in six Districts (year: 1990, 2003 \& 2011).

\begin{tabular}{llll}
\hline \multirow{2}{*}{ District } & Number of unit & & \\
\cline { 2 - 4 } & $\mathbf{1 9 9 0}$ & $\mathbf{2 0 0 3}$ & $\mathbf{2 0 1 1}$ \\
\hline Tangail & 10960 & 6476 & 6021 \\
Mymensingh & 620 & 671 & 492 \\
Narayanganj & 17231 & 5178 & 2323 \\
Narsingdi & 20511 & 7247 & 3141 \\
Kishoreganj & 1002 & 24 & 01 \\
Gazipur & 816 & 396 & 11 \\
\hline
\end{tabular}


Table 2. Number of number of looms (operational \& non-operational) in six Districts (year: 1990, 2003 \& 2011).

\begin{tabular}{|c|c|c|c|c|c|c|c|c|c|}
\hline \multirow{3}{*}{ District } & \multicolumn{9}{|c|}{ Number of looms } \\
\hline & \multicolumn{3}{|l|}{ Total } & \multicolumn{3}{|c|}{ Operational Looms } & \multicolumn{3}{|c|}{ Non-operational Looms } \\
\hline & 1990 & 2003 & 2011 & 1990 & 2003 & 2011 & 1990 & 2003 & 2011 \\
\hline Tangail & 34678 & 37222 & 35012 & 27697 & 30643 & 32574 & 6981 & 6579 & 3438 \\
\hline Mymensingh & 1047 & 1009 & 725 & 432 & 248 & 295 & 615 & 761 & 430 \\
\hline Narayanganj & 51468 & 14743 & 7358 & 42176 & 9960 & 6203 & 9292 & 4783 & 1155 \\
\hline Narsingdi & 59671 & 26693 & 12238 & 46364 & 14845 & 5380 & 13307 & 11848 & 6858 \\
\hline Gazipur & 3112 & 1763 & 44 & 1905 & 751 & 31 & 1207 & 1012 & 13 \\
\hline
\end{tabular}

Table 3. Total Person engaged in six Districts (Year: 1990, 2003 \& 2011).

\begin{tabular}{lll}
\hline \multirow{2}{*}{ District } & Person Engaged Total & \\
\cline { 2 - 3 } & $\mathbf{2 0 0 3}$ & $\mathbf{2 0 1 1}$ \\
\hline Tangail & 95316 & 54385 \\
Mymensingh & 779 & 1432 \\
Narayanganj & 35499 & 11215 \\
Narsingdi & 51291 & 7385 \\
Kishoreganj & 66 & 02 \\
Gazipur & 1955 & 89 \\
\hline
\end{tabular}

Jamdani is another famous handloom product which is produced from Narayanganj and Narsingdi. Narsingdi Sadar and Raipura upazila of Narsingdi district are famous for making different artistic sharee like jamdani, katan, bruket and titanic around $5.83 \%$ people are involved in weaving business in this district [13]. Basically Narayanganj is famous for jamdani sharee which are circulated in the whole country and abroad. Jamdanipalli is situated in Noapara which is $3 \mathrm{~km}$ away from Kanchpur Bridge to Sylhet district. In this Jamdani palli the price rate is too low that's why the wholesalers from Dhaka go there to buy jamdani sharee to display in their showroom [13]. Like those districts Mymensingh, Kishoreganj and Gazipur have number of loom and handloom weaving families [table 2]. They are also known for producing different loom and handloom products and selling them through markets.

\section{Data Analysis}

The findings have been analyzed descriptively from this primary and relevant secondary information. The figure 3 shows that the number of unit has been decreasing significantly in different six districts. Like in 1990 the number of unit in Narayanganj was 17231 which were 5175 in the year of 2003 and finally it has captured 2323 in $2011[15,16]$.

All other five districts are losing its number of factory that's why the culture of looms and handlooms is decreasing highly.

\section{Number of Unit}

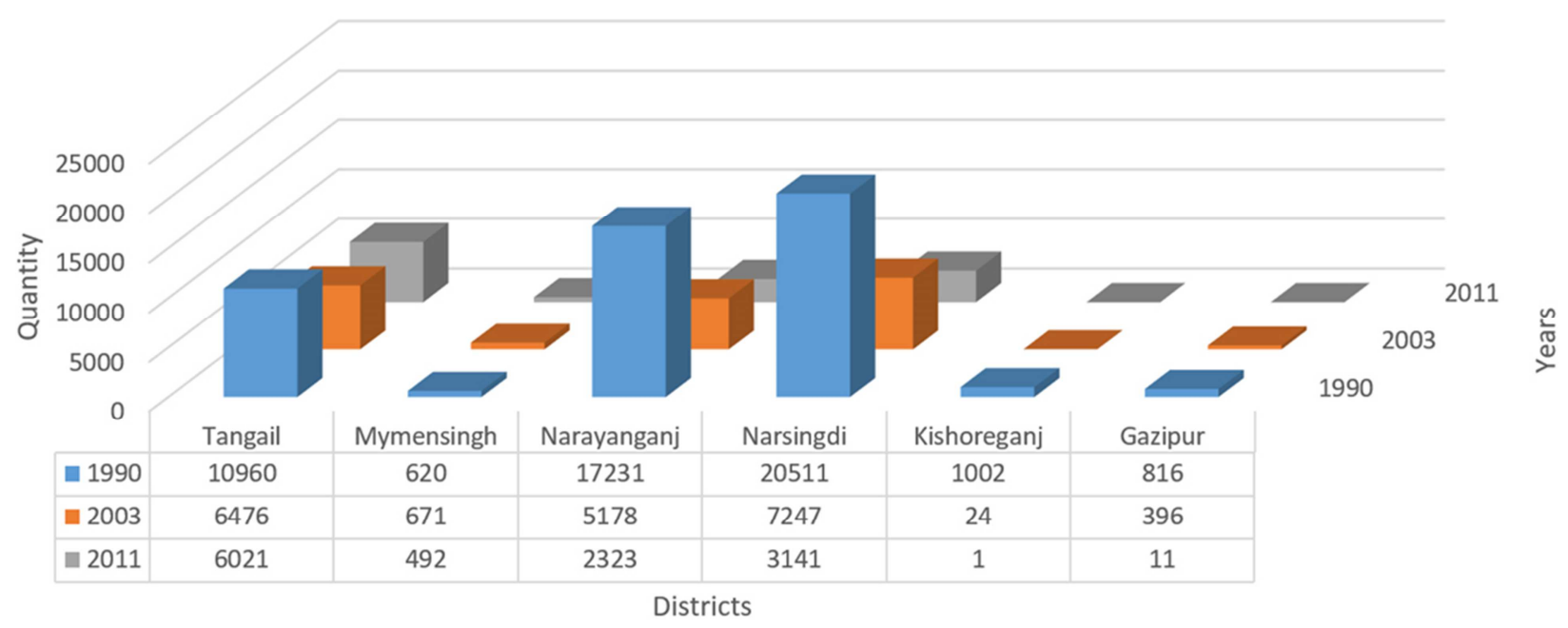


From the figure 4, figure 5 and figure 6 we can see the number of looms, operational and Non-operational has been decreasing significantly. In the year of 1990 total number of looms in Narayanganj was 51468 where Operational looms was 42176 and Non-Operational looms was 9292. Then in 2003 the number of total looms is 9960 in Narayanganj had decreased highly from the year 1990 which has been continuing into 2011. Both the Operational \& Non-operational looms in Narayanganj is also decreasing its number sequentially in 2003, 2011 from 1990. Just like as Narayanganj the same scenario is clearly seen in five Districts. Another important fact from those figure is found that the difference between Operational \& Non-operational looms is lessen in 2011 which was high in 1990 [15, 16].

\section{Total Number of Looms}

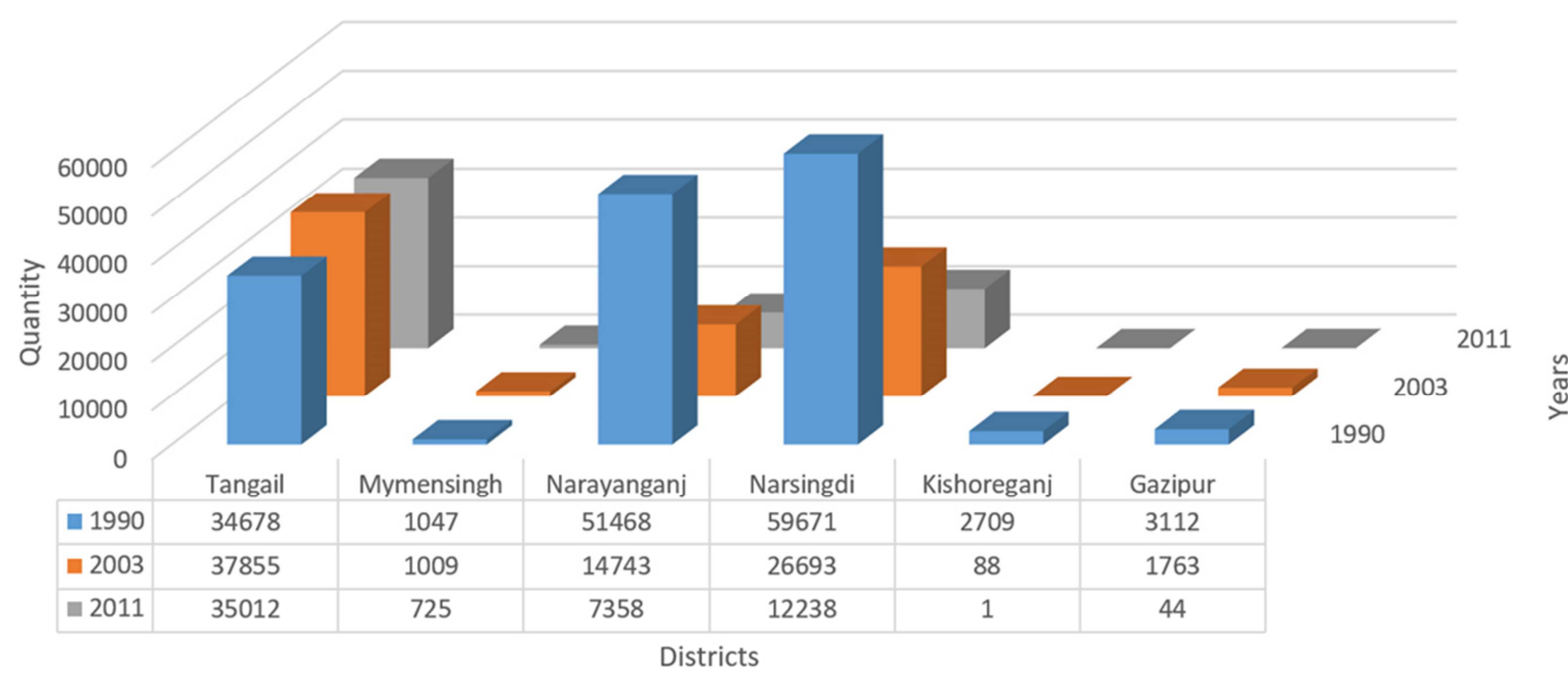

밈ㅁ 2011

Figure 4. Change of number of looms in the six Districts (Year: 1990, 2003 \& 2011.

\section{Number of Operational Looms}

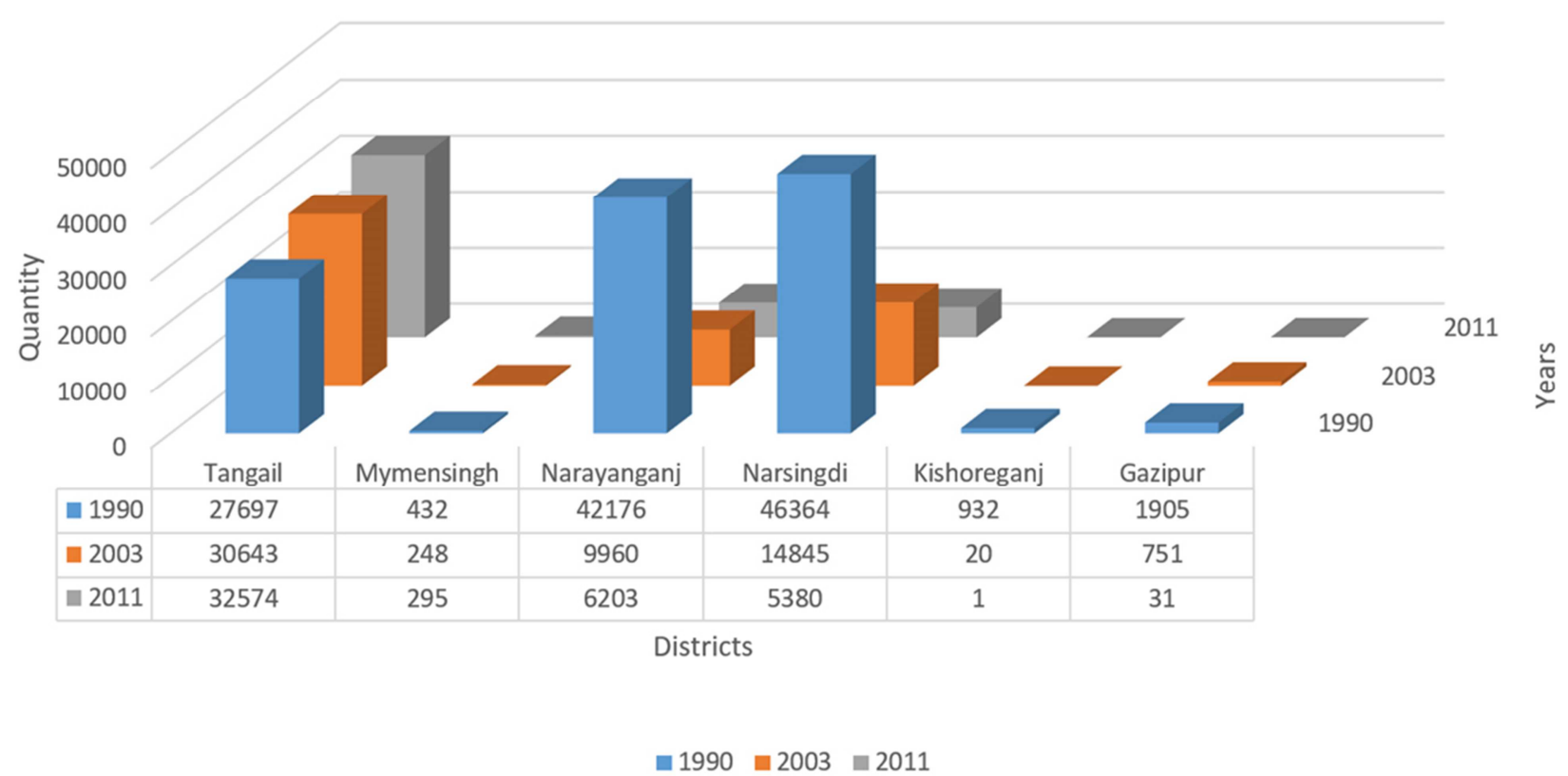

Figure 5. Change of number of operational looms in the six Districts (Year: 1990, 2003 \& 2011). 


\section{Number of Non-operational Looms}

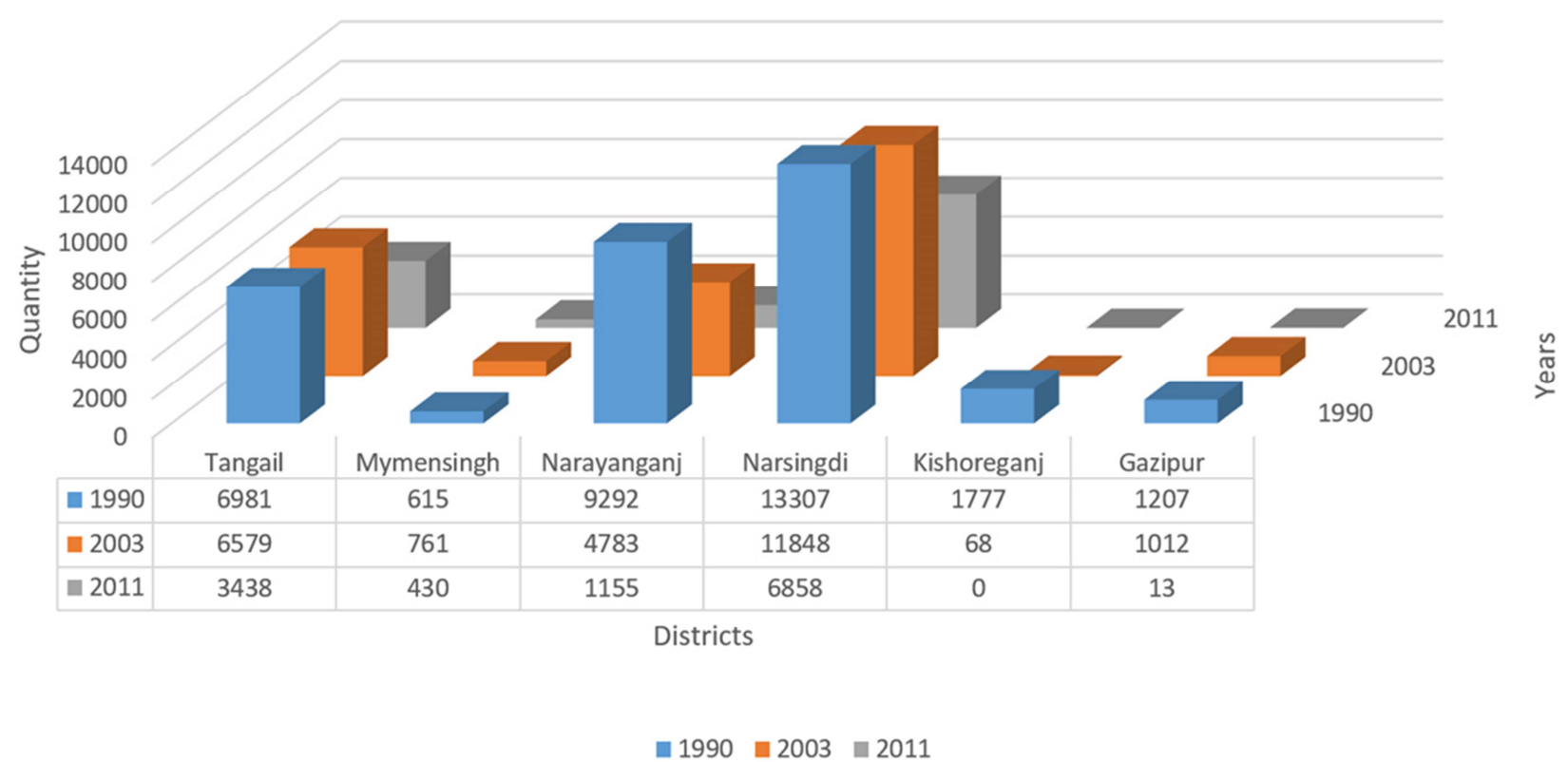

Figure 6. Change of number of non-operational looms in the six Districts (Year: 1990, 2003 \& 2011).

The figure 7 clearly showed that the number of total person engaged goes downward in the year of 2011 than 2003. Like
Total number of person engaged in Narayanganj was 35499 in 2003 which had lessened in 2011 and the number was 11215.

\section{Person engaged total}

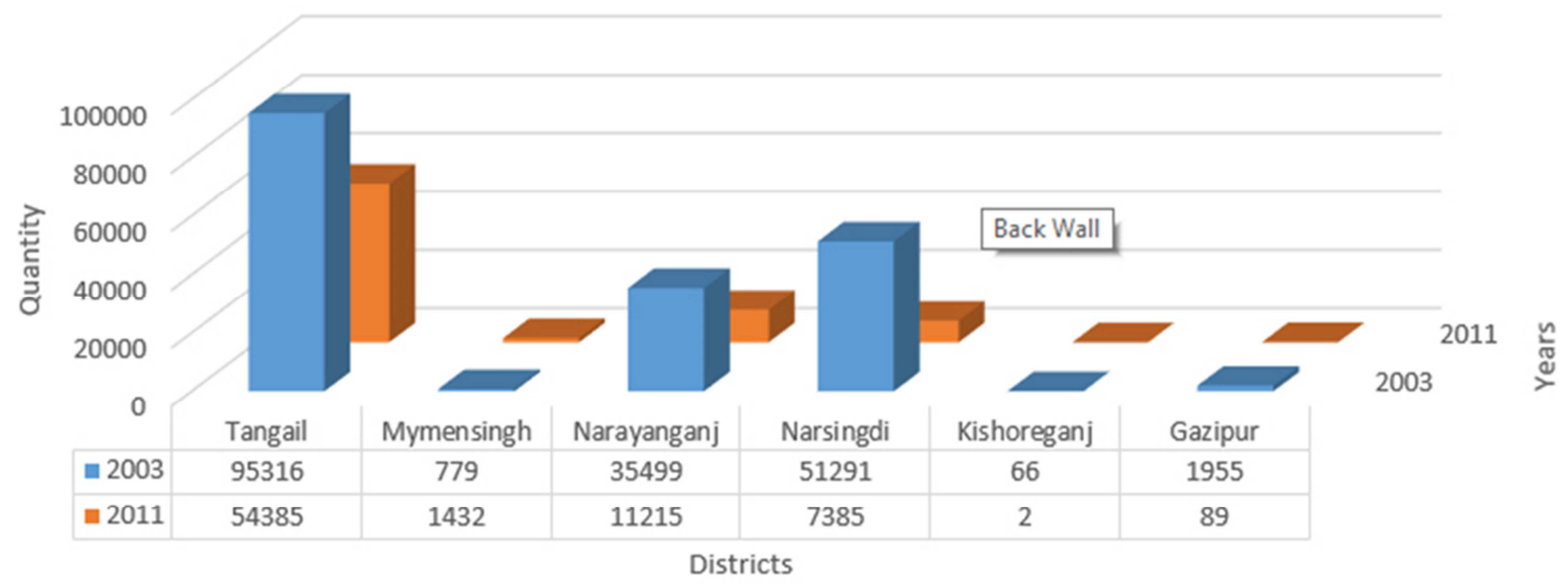

घ $2003 \square 2011$

Figure 7. Change of total engaged person in the six Districts (Year: 1990, $2003 \& 2011$ ).

\section{Findings and Recommendations}

From the data analysis we might have a clear view about how much the handloom industries of these selected areas have been suffering from the threat of extinction. The handloom products of these areas near Dhaka were widely recognized unique and reputed worldwide due to its originality, which the handloom workers learnt traditionally from the very beginning of this industry. Since 1990 to 2011 the number of loom units has dropped sharply due to the various reasons such as shortage of capital, increasing price of raw materials, insufficient transport facilities, inadequate technology and efficiency in operating the loom by the new generation, migration of the Bangladeshi weavers due to lack of security and better facilities in India are the factors those are slowing 
down the wheels of this industry [11]. Among the various causes the study has identified that mainly due to the shortage of space for making products and displaying them for selling and marketing to the buyers, lack of contemporary technology based marketing for more production and advertising, lack of preservation skill and absence of direct connection of the artisans to the local and international markets the products are losing their values. The skilled artisans become older and the young ones shifting their business or migrating to the neighboring countries due to the lack of profit from this industry. Thus the communities are breaking down and cause a rapid decline of handloom industries of these areas. More over government and non- government organizations are failed to implement any policy support to industrialize the products nationally and internationally.

The making process of handloom clothes need sophisticated competence and concentration of the weavers for both designing and in making process According to Bangladesh Handloom Board Profile: BHB, Dhaka 2012, proper place for both production and marketing is mandatory to reveal the relationships among family, work, and community in this highly specialized occupation [4]. The handloom products have been sold in the nearest haat of once or twice in every week. The consumers of this haat are mainly retailers who buy products from the weavers and supplies in all over the country. In their glorious days the weavers sold handloom products about a remarkable amount of money. But in recent years the market of the traditional handloom products are declining manly due to the product diversification and organizational and industrialization problem. Moreover Fashion houses of Dhaka and other retailers from all over the country come to this haat and buy products according to their demand from the local weavers at low price. Sometimes the weavers are bound to design the products according to retailers' choice and sell these at very cheap price to sustain their business. Thus the products are losing its originality and remain as secondary source of the business. As the weavers are not getting the profit and no longer able to hold its past glory thus the interest of next generations towards craftsmanship are also declining from their ancestors' traditional business.

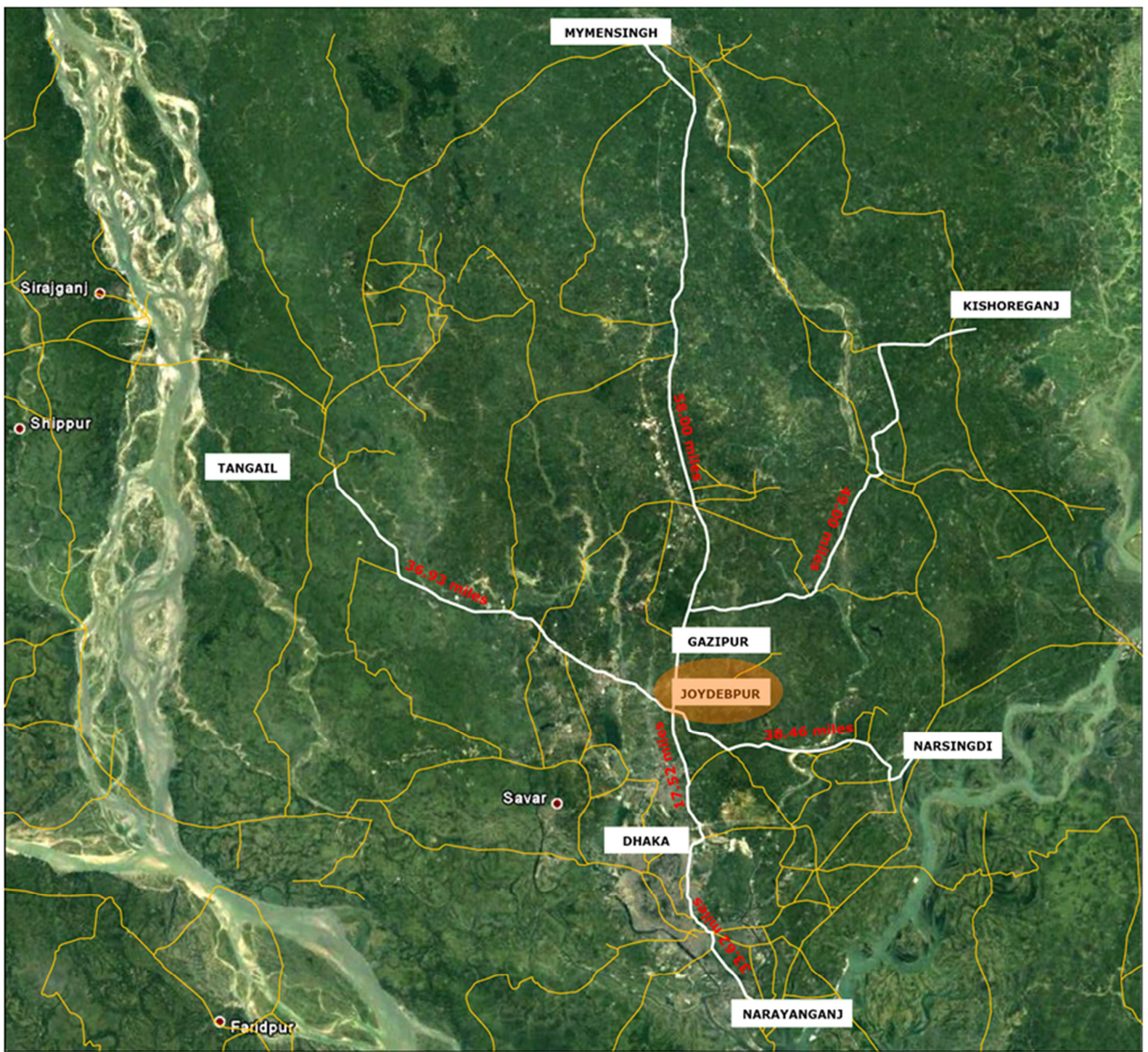

Figure 8. Accessible Roads towards the proposed site from the six selected Zones. 


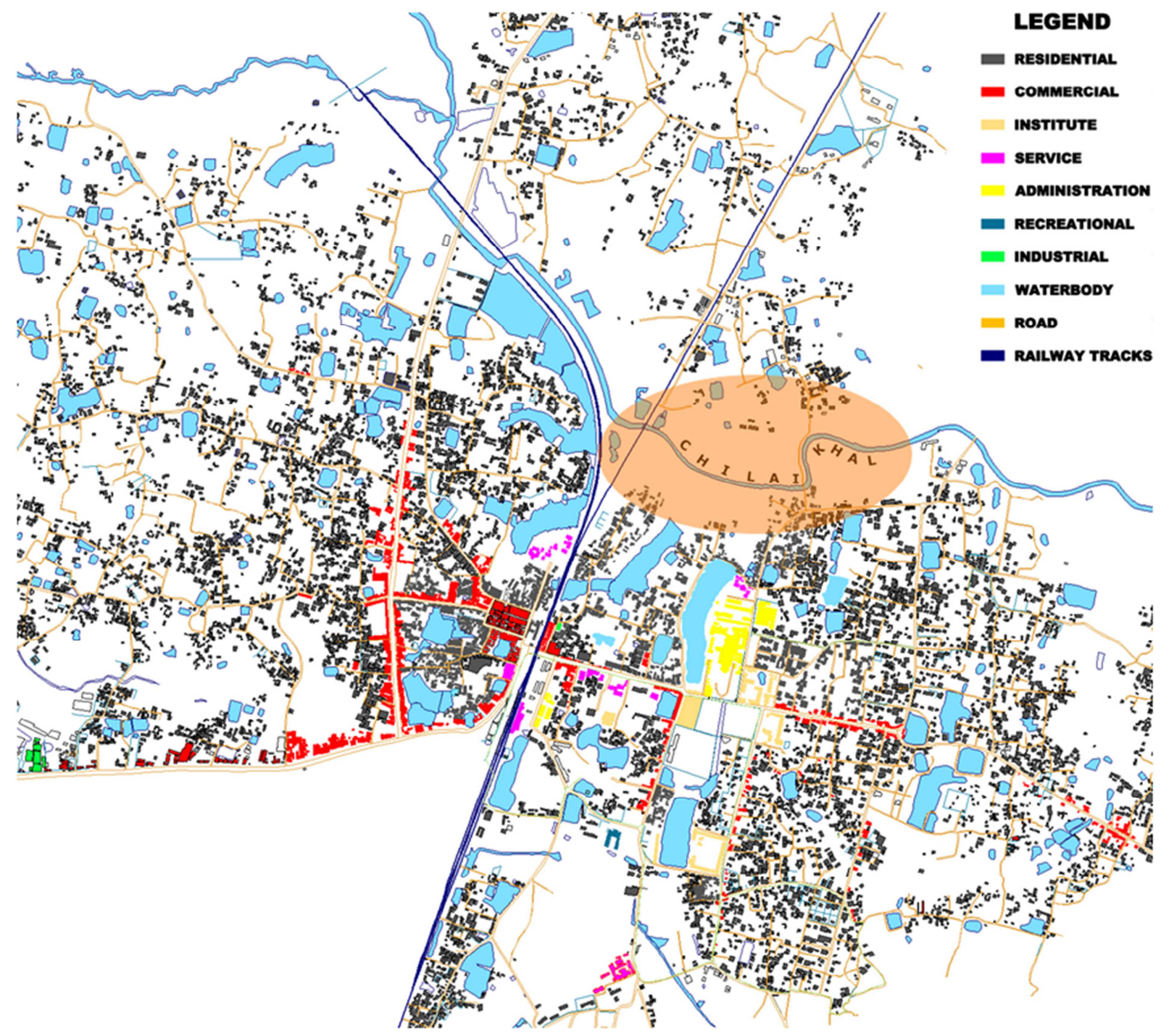

Figure 9. Location of Proposed Site.

The clothing sector of Bangladesh is the premier sector of the country in terms of export earning, GDP, industrial value addition and employment generation. Clothing industries of Bangladesh for cheap labor cost are more preferable to the international buyers. Due to the availability of all recourses and better communication about $50 \%$ clothing manufacturing units are situated in and around the capital city of Dhaka. Thus the city has become exhausted due to the huge build form and population explosion, which has a direct impact on environmental and socio-cultural norms of Dhaka. To overcome the situation the clothing organizations like BGMEA, BKMEA and BTA asking the Government to take initiative to relocate and restructure this sector for sustainable growth. The experts recommend relocating these industries to Keraniganj and Gazaria near Dhaka, where basic model of industrial cluster are present. To relocate the industries except the parks, agriculture land and forest, only wetlands can be utilized to maintain regional ecosystem and socio-cultural norm. Relocation of the industries to the different location out of Dhaka will reduce the pollution and traffic congestion and keep the city free from uncountable noted problems. [7].
In this research, the handloom communities in the six districts of the study areas have goodwill to extend their hereditary business but analysis shows that the growth and market share is not satisfactory of this industry to the national and global context. From the above case of the clothing sector it is suggested that relocating and restructuring of these weaver communities may retain the handloom sector from extinction and create job opportunities and expand local and global connection. To operate the business effectively it must be needed to build a common platform to enlarge production and display the handloom products to different people through some government or non-government programs or projects thus to appeal and attract more people, more partners, more resources to participate in the platform, and thus benefit more people, that is the key issue to developing these craft business.

Figure 8 and Figure 9 shows that the six selected zones, where most of the craft families live, are very close to each other and around 18 miles catchment distance from Dhaka thus easily accessible through road from the capital city. After analysis it is suggested that the orange marked zone both Figure 8 and Figure 9, which is located near Chilai Khal at 
Gazipur Sadar, which is a vacant Government land about 30 acres would be the best interconnected location for creating an international business hub. The reasons for choosing the place is for easy (30 miles) accessibility from all the six selected zones as well as, Dhaka city. Moreover this area is directly connected with water ways through Chilai Khal which ensures the easy transportation of raw materials and products. Here in Figure 8 the white marked line shows the main artery road and yellow line represents the secondary connecting roads. The study recommends providing a business hub at Gazipur Sadar to exhibit the heritage of handloom products where all the craftsmen from all over the country could display and sell their original products by their own nationally and internationally, as they did years before in the village haat. At the same time the craftsmen from other countries can also come to this hub and sell their products which will contribute to the country's economy. This study attempts to integrate resources of handloom craftsmen to strengthen their expertise and branding them worldwide. It also aims to revitalize the handloom community and to foster the next-generation in their traditional family business with modern technologies along with creativity and originality.

\section{References}

[1] Ahmed M U. "Development of Small- scale industries in Bangladesh in the New Millennium": Challenges and Opportunities 1999, Asian Affairs, Vol. 21, NO. 1, Jan-march.

[2] Latif, Muhammad Abdul. 1997. Handloom Industry of Bangladesh 1947-1990. Dhaka: University Press Ltd.

[3] http://worldpopulationreview.com/countries/bangladesh-popul ation/?fbclid=IwAR1GSWUmU_spPA2ScREtCP4zuC5RkTZ anTFZSX7zZu21eElS6yOKn2padPw

[4] Rahman M. Prospects of Handloom Industries in Pabna, Bangladesh. Global journal of management and business research interdisciplinary 2013; Volume 13, Issue 5: 8-17.
[5] Bangladesh Handloom Board Profile: BHB, Dhaka 2012.

[6] Liton M. R. I, Islam, T. \&Saha, S. Present Scenario and Future Challenges in Handloom Industry in Bangladesh 2016. Social Science; Science Publishing Group; Volume 5, Issue 5, October 2016, Pages: 70-76.

[7] Apu A A. Relocation of clothing industry of Dhaka must to create competitiveness and returning normalcy in Dhaka. Textile today, 2012.

[8] Banarjee S., Muzaib M., Sharmin S. Study of Handloom Workers and Causes of Their Migration: A Study in Handloom Industry of Tangail District, Bangladesh. Research on humanities and social sciences 2014; vol. 4 no. 22: 157-162.

[9] Khondoker, A. M and Sonobe, T. 2011, Determinants of Small Enterprises' Performance in Developing Countries: A Bangladesh Case, The National Graudate Institute For Policy Studies (GRIPS), Tokyo, Japan, January 2011. Online at https://mpra.ub.uni-muenchen.de/44006/ MPRA Paper No. 44006, posted 27 January 2013 00: 27 UTC.

[10] Islam M K, Hossain M E. An analysis of Present Scenario of Handloom Weaving Industry in Bangladesh. Rabindra Journal 2012; Volume. 03, No. 1: 13-28.

[11] Sobhan R. Employment and Social Issues in the Formulation of Policy for the Handloom Industry. The Bangladesh Development Studies 1989, Volume XVII, Nos. 2 \& 1.

[12] District Statistics. Statistics and informatics divisions (SID), Ministry of planning, Government of the people's republic of Bangladesh: Bangladesh bureau of statistics (BBS), 2011.

[13] Ghosh S K, Akter M S. Handloom Industry on the Way of Extinction: An empirical SStudy Over the Pre- dominant Factors. BRAC university journal 2005; Vol. II, No. 2: 1-12.

[14] Rabby M F. Green Fashion Made in Handloom. Textile today, 2012.

[15] Jamdani Polli, Tuesday, August 24, 2010.

[16] Report on Bangladesh Handloom Census. Planning division, Ministry of planning: Bangladesh bureau of statistics, 1990, 2003, 2011. 